\title{
Estimation of Global Radiations in the Ultraviolet, Visible and Infrared Regions
}

\author{
by \\ Muneyasu Kano, Masaatsu Miyauchi and Masashi Suzuki \\ Meteorological Research Institute, Tokyo
}

(Received July 5, 1978)

\begin{abstract}
We constructed spectral pyranometers that can measure the spectral global radiation properly Using these pyranometers the simultaneous measurements of global radiations in the infrared, infrared to visible and infrared to ultraviolet (entire spectral) regions were carried out to examine the relations between the global radiations in the infrared, visible and ultraviolet regions and the global radiation in the entire spectral region. It was found that the global radiations in the infrared, visible and ultraviolet regions $S_{I}, S_{V}$, and $S_{U}$ can be estimated with enough accuracy from the global radiation in the entire spectral region $S$ by the following equation :
\end{abstract}

$$
S_{K}=A_{K} S+B_{K} S^{n+1} \quad(K=I, V, U)
$$

where $n$ is a numerical constant.

\section{Introduction.}

In Japan the global radiation in the entire spectral region is measured at the main meteorological observatories, which number several dozens, and the data are offered to the operational and research works in meteorology and other fields such as architecture, agriculture, medicine, etc. In addition to these data, there has been, in recent times, increased demand for data on global radiation broken down into the ultraviolet, visible and infrared regions. Unfortunately the global radiation in each of the above spectral regions is not measured at the meteorological observatories at present.

In order to examine the possibility of estimation of the global radiation in each of the above three spectral regions from the overall global radiation, we measured the global radiation individually in the above three spectral regions and in the entire spectral region for about a year from Fall in 1975 to Summer in 1976 at the Meteorological Research Institute in Tokyo and studied the relations between the global radiations in the three spectral regions and the global radiation in the entire spectral region which has been measured at the above meteorological observatories distributed almost uniformly in Japan.

\section{Measurements of global radiations in the ultraviolet, visible and infrared regions}

In measuring the global radiations in various spectral regions there have been used pyranometers with sensors of photoelectric tube. The sensitivities of these sensors have large spectral and temperature dependencies (e.g. Robinson, 1966). Owing to this, some difficulties occur in calibration of these pyranometers. Furthermore the values measured with these pyranometers deviate considerably from the so-called cosine-law, which states that in an ideal pyranometer the output varies with the cosine of the incident angle of radiation (e. g. Sekihara et al. 1961). It is, therefore, difficult to obtain global radiations 
in the spectral regions with enough accuracy with these pyranometers. In order to remove or lessen these defects, we constructed pyranometers that can measure global radiation in the infrared, visible and ultraviolet regions by installing the Schott spherical

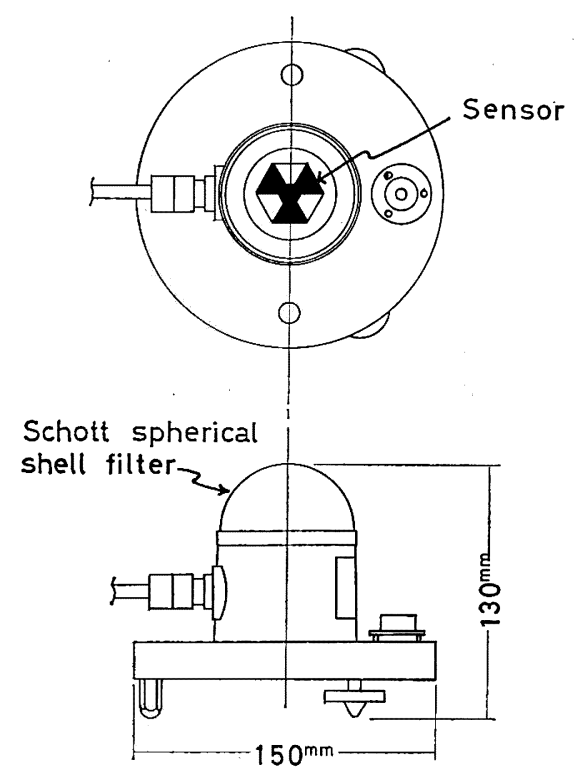

Fig. 1. Schematic diagram of the spectral pyranometer. shell filters of RG 715, GG 395 and WG 230 instead of the ordinary glass dome of the pyranometer used for the measurement of global radiation in the entire spectral region.

The main characteristics of these pyranometers are as follows: In Fig. 1 is shown their appearance. The transmittances of the above three filters are shown.in Fig. 2. From the figure the transmittances of the filters are nearly constant except for the boundary regions of each spectrum. At the earth's surface the amount of solar radiation, whose wavelength is smaller than $300 \mathrm{~nm}$ is negligible, and that whose wavelength is larger than $3000 \mathrm{~nm}$ is only a few percent of the total. The transmittances of the filters of GG 395 and RG 715 are sharply defined in the regions around $395 \mathrm{~nm}$ and $715 \mathrm{~nm}$. Therefore the transmittances of the filters are approximated with the dotted lines in the figure without any serious errors. In Fig. 3 are shown the dependencies of the output of the pyranometers on the incident angle of radiation. From the figure, it is found that the pyranometers obey satisfactorily the so-called cosine law. Furthermore the sensors are expected to have little dependency in their

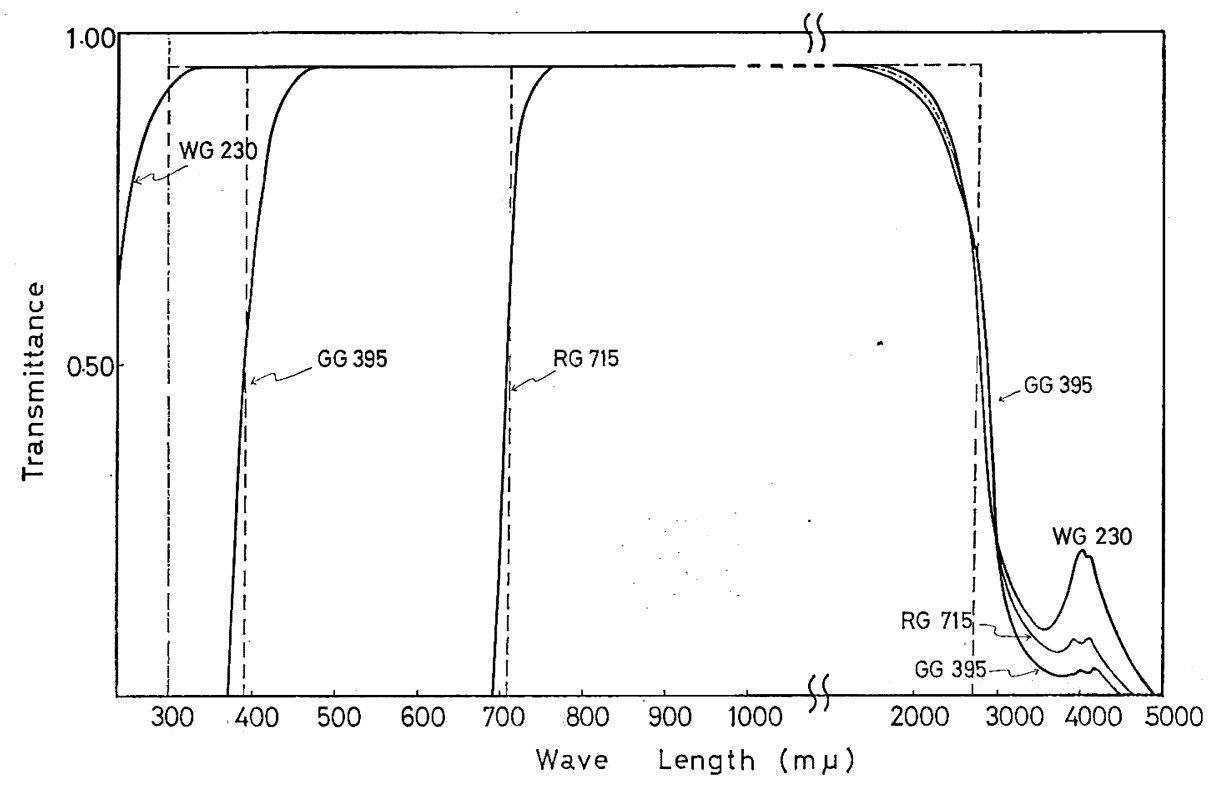

Fig. 2. Transmittances of the Schott filters RG 715, GG 395 and WG 230 used in the spectral pyranometers. 


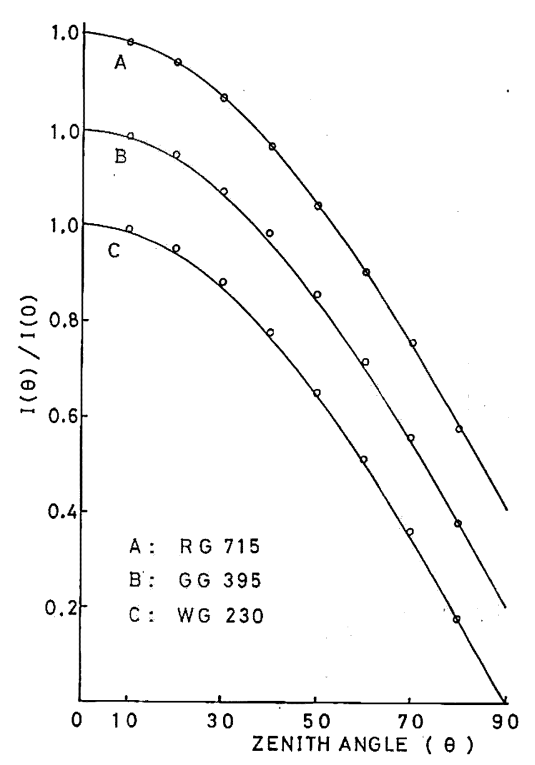

Fig. 3. Dependencies of outputs of the spectral pyranometers on the incident angle of the radiation. In the figure, o denotes the measured values and the solid cur. ves those of cosine.
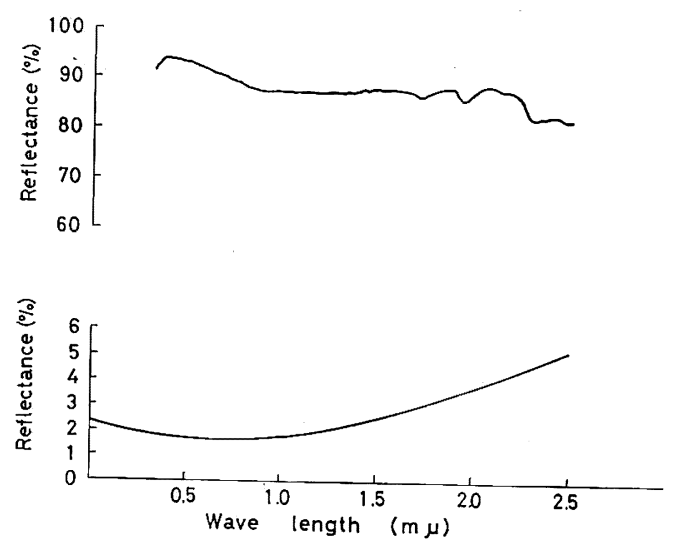

Fig. 4. Spetral reflectances of white paint (shown above) (data of Eastman white reflectance coating) and black paint (shown below) (after Blevin et al., 1966). The sensor surfaces of pyranometers used are painted with these paints.

sensitivity on the wavelength from Fig. 4, in which the reflectances of black and white paints composing the sensor surface of the pyranometer are shown.

Next, we will describe the calibration (the determination of conversion factor from output to radiation) of the above spectral pyranometers. For the calibration, the simultaneous measurements of solar radiation by the above sepectral pyranometers and an Ångstrom compensation pyrheliometer with plane filters of RG 715 and GG 395 and WG 230 are carried out in a clear and stable day. In this case the radiation measured by the Angstrom compensation pyrheliometer is the direct solar radiation reduced by the magnitude of transmittance of the filter in each spectral region. As the transmittance of each filter is regarded as a constant value (rectangular approximation of filter transmittance), the diredt solar radiation in each spectral region is obtained by dividing the radiation measured with the Angstrom compensation pyrheliometer by the transmittance of each filter. As a sensitivity of the sensor of each spectral pyranometer is nearly independent of wavelength as mentioned above, the output of each spectral pyranometer is proportional to the magnitude of the global radiation in each spectral region unless the spectral distribution of global radiation varies extremely. By shielding the direct solar radiation with a shadow ring, the output proportional to the scattered radiation in a horizontal plane is obtained in each spectral region. The output proportional to the global radiation and to the scattered radiation in a horizontal plane is obtained alternately by shielding and unshielding the direct solar radiation in turn. From the difference of these two outputs, the output proportional to the direct solar radiation in a horizontal plane is obtained. Thus the calibration factor $K$ is obtained as follows :

$$
K \times \Delta V=I \cos \theta
$$

where $\Delta V$ is the output of each spectral pyranometer which is proportional to the direct solar radiation in a horizontal plane, $I$ the direct solar radiation, and $\theta$ the zenith angle of the sun. Using the calibration factor $K$ thus obtained, the absolute value of the global radiation in each spectral region is easily obtained from the output of each spectral pyranometer. 
The global radiations measured by the spectral pyranometers with filters of RG 715, GG 395 and WG 230 correspond respectively to the global radiations of the infrared region ranging approximately from $710 \mathrm{~mm}$ to $2700 \mathrm{~mm}$, of the infrared to visible region ranging approximately from $395 \mathrm{~nm}$ to 2700 $\mathrm{nm}$ and of the infrared to ultraviolet region ranging approximately from $300 \mathrm{~nm}$ to 2700 nm. For these measured values, the addition (correction) of radiations in the infrared region, in which the filter transmittion is zero or nearly zero, are carried out on the basis of the measurements by the Anggstrom pyrheliometer with or without the above filters. Therefore the global radiations measured by pyranometers with the RG 715 filter and the WG 230 filter are respectively those in the infrared region whose wavelength is larger than $710 \mathrm{~nm}$ and in the entire spectral region. The difference between the global radiation measured by the pyranometer with the GG 395 filter and that by the pyranometer with the RG 715 filter gives the global radiation in the visible region ranging approximately from $395 \mathrm{~nm}$ to $710 \mathrm{~nm}$. Similarly the difference between the global radiation measured by the pyranometer with the WG 230 filter and that by the pyranometer with the GG 395 filter gives the global radiation in the ultraviolet region ranging approximately from $300 \mathrm{~nm}$ to $395 \mathrm{~nm}$.

In the following section we will examine the relations between the global radiations in the infrared, visible and ultraviolet regions and the global radiation in the entire spectral region and give the empirical expressions which are employed to estimate the global radiations in the above three spectral regions using the global radiation in the entire spectral region.

\section{Results obtained}

In Figs. 5a, 5b and $5 \mathrm{c}$ are shown the relations between the global radiations in the above three spectral regions and the global radiation in the entire spectral region in various solar altitudes. In the figures, the

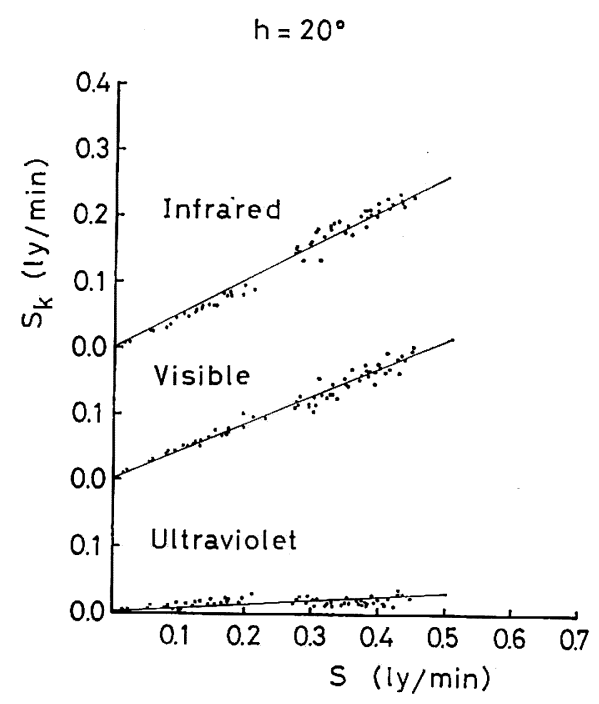

Fig. 5a. Relations of the global radiations in the infrared, visible and ultraviolet regions to the global radiation in the entire spectral region (solid curves) with the measured values denoted by dots at the solar altitude of $20^{\circ}$.

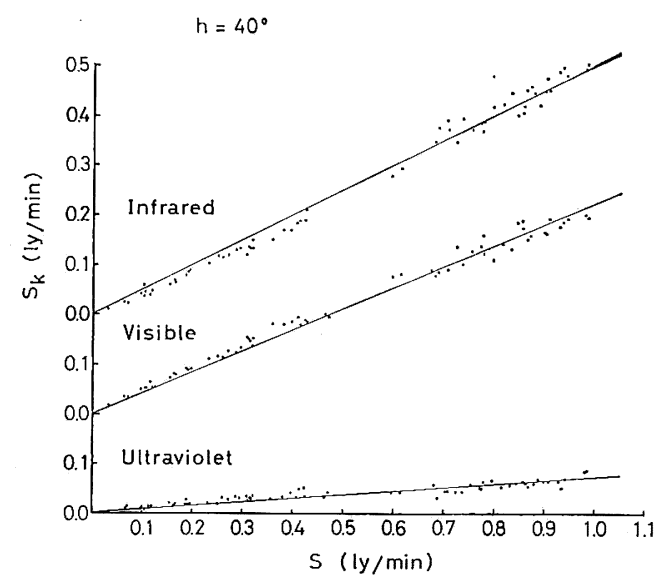

Fig. 5b. The same as Fig. 5a except for the solar altitude of $40^{\circ}$.

abscissa is the global solar radiation in the entire spectral region (to be denoted by $S$ below) and the ordinate the global solar radiation in the infrared, visible and ultraviolet regions (to be denoted respectively by $S_{I}, S_{V}$ and $S_{U}$ below). In the figures, the measured values are denoted by dots, while the solid lines are the regression lines expressed by 


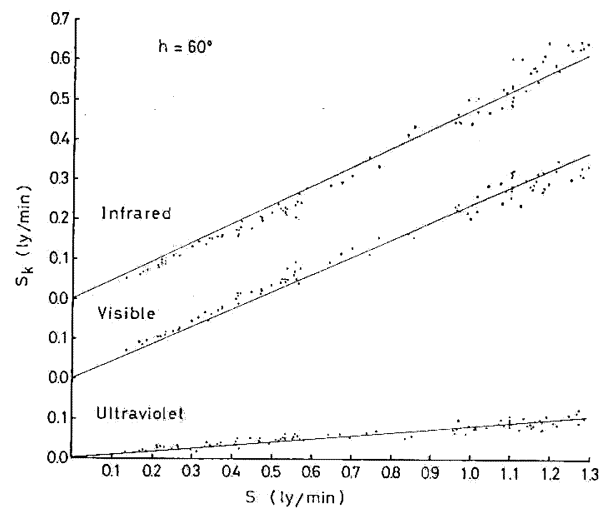

Fig. 5c. The same as Fig. 5a except for the solar altitude of $60^{\circ}$.

$$
S_{K}=a_{K} S \quad(K=I, V, U)
$$

obtained from the measured values. Here $S_{K}$ denotes the global solar radiation in each spectral region, $S$ that in the entire spectral region, and $a_{K}$ is a numerical constant given in Table 1. The measurements were carried out in all weather conditions except for rain and snow. In the figures smaller $S$ corresponds to cloudy days and larger to clear days. As seen from the figures, $S_{I}, S_{V}$ and $S_{U}$ vary almost linearly with $S$. Observing the figures carefully, however, the measured values of $S_{I}$ are located under the regression

Table 1. Numerical constants used for estimations of global radiations in the ultraviolet, visible and infrared regions.

\begin{tabular}{|c|c|c|c|c|c|c|}
\hline & $20^{\circ}$ & $30^{\circ}$ & $40^{\circ}$ & $50^{\circ}$ & $60^{\circ}$ & $70^{\circ}$ \\
\hline$a_{I}$ & 0.522 & 0.517 & 0.499 & 0.483 & 0.477 & 0.475 \\
\hline$a_{V}$ & 0.422 & 0.417 & 0.425 & 0.435 & 0.438 & 0.445 \\
\hline$a_{U}$ & 0.0561 & 0.0661 & 0.0760 & 0.0820 & 0.0842 & 0.0798 \\
\hline$A_{I}$ & 0.338 & 0.350 & 0.329 & 0.334 & 0.328 & 0.357 \\
\hline$A_{V}$ & 0.494 & 0.505 & 0.529 & 0.526 & 0.546 & 0.526 \\
\hline$A_{U}$ & 0.168 & 0.145 & 0.142 & 0.140 & 0.138 & 0.122 \\
\hline$B_{I}$ & 0.313 & 0.212 & 0.195 & 0.158 & 0.148 & 0.112 \\
\hline$B_{V}$ & -0.125 & -0.111 & -0.121 & -0.0966 & -0.106 & -0.0765 \\
\hline$B_{U}$ & -0.187 & -0.100 & -0.0750 & -0.0614 & -0.0519 & -0.0395 \\
\hline$n$ & 0.5 & 0.5 & 0.5 & 0.5 & 0.5 & 0.5 \\
\hline
\end{tabular}

lines in the left hand side of the figures and above the regression lines in the right hand side. For $S_{V}$ and $S_{U}$ the opposites are observed. That is, the measured value of $S_{I}$ is relatively small in the smaller part of $S$ (cloudy days) and larger in the larger part of $S$ (clear days), while the messured values of $S_{V}$ and $S_{U}$ show the opposities. The turning points, at which the measured values pass from underneath the regression lines to above or from above the regression lines to underneath, shift towards the larger part of $S$ with the increase of solar height, as expected. The above systematic deviation of the measured values from the regression lines can be more clearly shown by the relations of $S_{I} / S, S_{V} / S$ and $S_{U} / S$ to $S$. The results are shown in Figs. 6a, $6 \mathrm{~b}$ and $6 \mathrm{c}$, where the measured values are denoted by dots and the solid curves are those obtained by the least square method using the measured values and are given by the following equation :

$$
\frac{\mathrm{S}_{K}}{S}=A_{K}+B_{K} S^{n}
$$

where $A_{K}$ and $B_{K}(K=I, V, U)$ and $n$ are the numerical constants as given in Table 1 . As shown in the figure, $S_{I} / S$ is small for the small value of $S$ and increases rapidly as $S$ increases and reaches to a nearly constant value beyond a certain value of $S$ which depends on the solar altitude. On the contrary, $S_{V} / S$ is large for the small value 


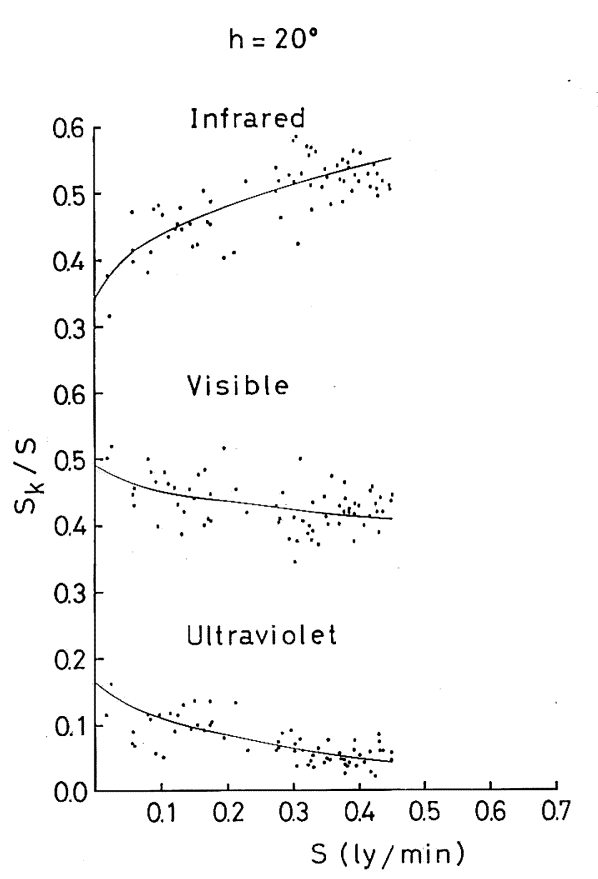

Fig. 6a. The relations of the fractional amounts of the global radiations in the infrared, visible and ultra. violet regions to the global radiation in the entire spectral region (solid curves) with the measured values denoted by dots at the solar altitude of $20^{\circ}$.

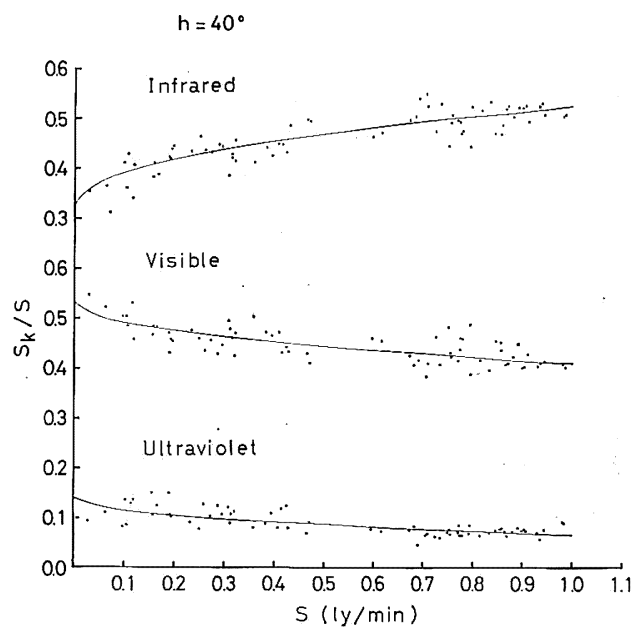

Fig. 6b. The same as Fig. 6a except for the solar altitude of $40^{\circ}$.

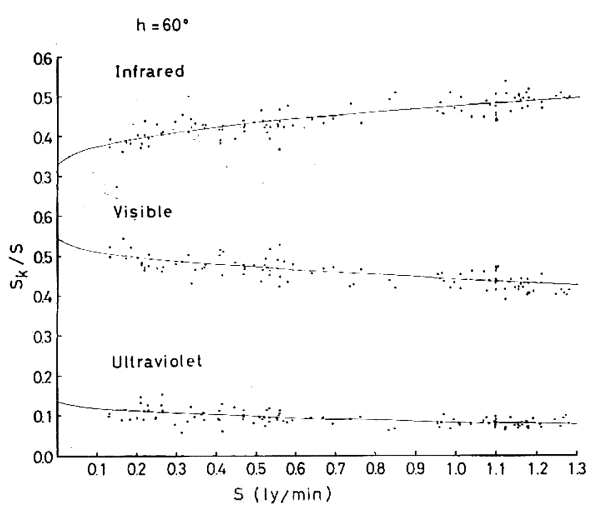

Fig. 6c. The same as Fig. 6a except for the solar altitude of $60^{\circ}$.

of $S$ and decreases rather rapidly as $S$ increases and reaches to a nearly constant value beyond a certain values of $S$.

The results described above can be explained as follows: In cloudy weather (small $S)$, the extinctinon of solar radiation is mainly due to the scattering and absorption by cloud particles and the absorption by the water vapor which is naturally more abundant on cloudy days. The absorption of

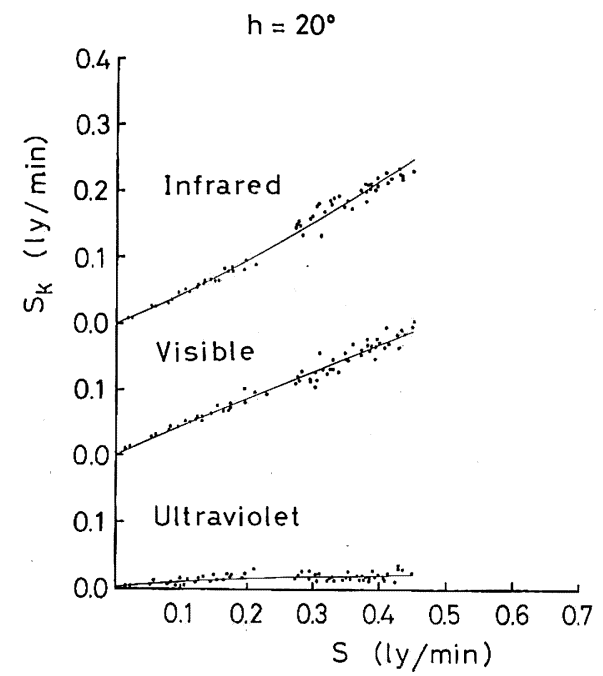

Fig. 7a. Improved relations of global radiations in the infrared, visible and ultraviolet regions to the global radiation in the entire spectral region (solid curves) with the measure values denoted by dots at the solar altitude of $20^{\circ}$. 
solar radiation by water vapor mainly occur in the infrared region and hardly in the other spectral regions. Therefore $S_{I} / S$ is small at the smaller part of $S$ (cloudy day) and as the cloudiness decreases ( $S$ increses) the absorption becomes smaller and consequently $S_{I} / S$ becomes larger and reaches a nearly constant value in a clear day. In the visible and ultraviolet regions, $S_{V} / S$ and $S_{U} / S$ decreases or increase according to the increase or decrease of $S_{I} / S$.

From the above discussions the global radiations in the infrared, visible and ultra-

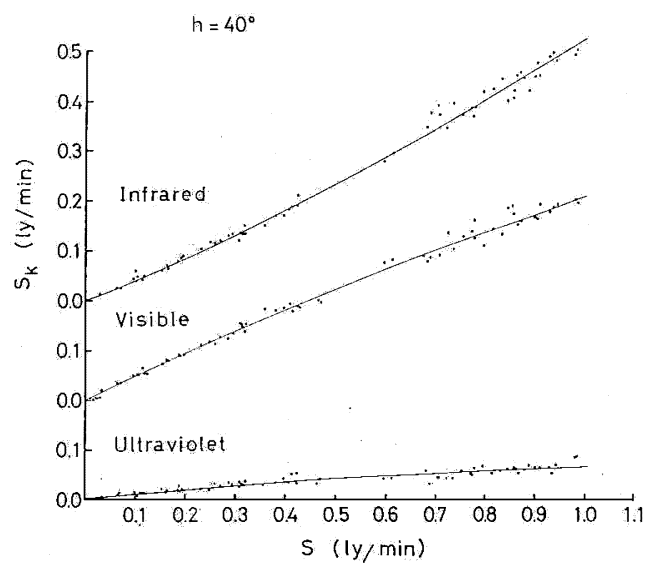

Fig. 7b. The same as Fig. 7a except for the solar altitude of $40^{\circ}$.

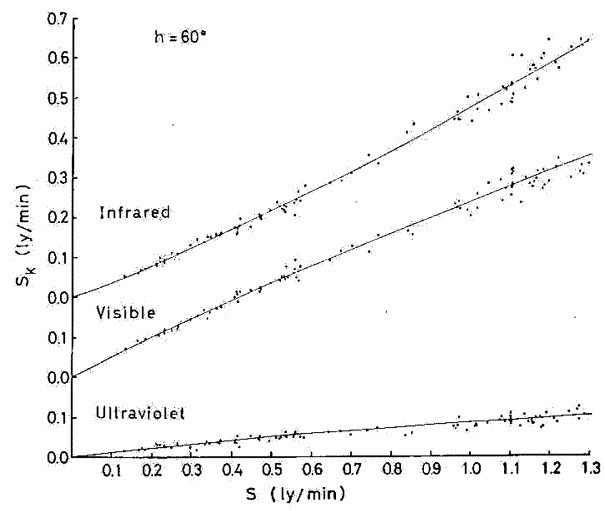

Fig. 7c. The same as Fig. 7a except for the solar altitude of $60^{\circ}$. violet $S_{I}, S_{V}$ and $S_{U}$ can be expressed more precisely by Equation (3) which is equivalent to Equation (2)

$$
S_{K}=A_{K} S+B_{K} S^{n+1}
$$

The results are shown in Figs. $7 \mathrm{a}, 7 \mathrm{~b}$, and $7 \mathrm{c}$. It is found from the figures that Equation (3) gives the global radiation in the above three spectral regions with enough accuracy from the global radiation in tne entire spectral region.

\section{Coclusion}

As shown in the preceding section, the global solar radiations in the infrared, visible and ultraviolet regions $S_{I}, S_{V}$ and $S_{U}$ are related to the global solar radiation in the entire spectral region $S$ roughly by (2) or more precisely by (3). That is, $S_{I}, S_{V}$ and $S_{U}$ can be estimated with enough accuracy from $S$, which can be obtained at the main meteorological observatories in the world, by Eq. (3)

Acknowledgement:- The authors express their thanks to Mrs. H. Shimura and F. Matsubara, Japan Meterological Agency, and Mr. Miyake, Eko Seiki Co. Ltd., for their kind helps in various examinations on the pyranometers and also to Miss M. Uno for her assistance in drawing the figures.

\section{References}

Blevin, W.R. and W. J. Brown, 1966: Black coating for absolute radiometers. Meteorologia, 2, 139

Robinson, N., 1966: Solar Radiation, pp. 347 Elsevier pub. Co.

Sekihara, K., M. Murai, M. Kano, Y. Ogawa and R. Mukai, 1961: Measurements of ultraviolet, visible and infrared solar and sky radiation in relation to meteorological conditions. (in Japanese) Report of Meteorological Reseach $13,23-29$ 


\section{紫外，可視および赤外域における水平面日射量の評価}

\section{嘉納宗靖・宮内正厚・鈴木 正}

全波長域の水灭面日射量快周知のと括り，気象のみならず，建築，農業，医学等各方面に広く使われ，それらの 分野に貢献している。最近になって, このほか紫外, 可視, 赤外域の水平面日射量の観測資料が各方面から要望さ れている。残念なことに, これらの連続観測は皆無に近い。この研究では, これら紫外, 可視, 赤外域の水平面日 射量を測定なる日射計を製作し，これを用いて，約 1 ケ年間観測を抏こなって，これら波長域の水平面日射量と全 波長域水平面日射量との関係を研究した。これょり，国内数10ケ所の気像観測所等でルーチン業務で測定されてい る全波長域水平面日射量 $(S)$ を用いて，上記 3 波長域の水平面日射量 $\left(S_{K}, K\right.$ は波長域を示す）を精度よく評価出 来る次の実験式を見出した。

$$
S_{K}=A_{K} S+B_{K} S^{n+1}
$$

こつで $A_{K}, B_{K}, n$ は定数である。 